\title{
Medievalista
}

Online

$24 \mid 2018$

Número 24

\section{Iñaki Martín Viso, Asentamientos y paisajes rurales en el Occidente medieval}

Gonzalo J. Escudero Manzano

\section{OpenEdition}

1 Journals

\section{Edição electrónica}

URL: http://journals.openedition.org/medievalista/1706

DOI: 10.4000/medievalista.1706

ISSN: 1646-740X

\section{Editora}

Instituto de Estudos Medievais - FCSH-UNL

\section{Refêrencia eletrónica}

Gonzalo J. Escudero Manzano, «Iñaki Martín Viso, Asentamientos y paisajes rurales en el Occidente medieval », Medievalista [Online], 24 | 2018, posto online no dia 16 março 2019, consultado o 23 setembro 2020. URL : http://journals.openedition.org/medievalista/1706 ; DOI : https://doi.org/ 10.4000/medievalista.1706

Este documento foi criado de forma automática no dia 23 setembro 2020.

Mediavalista está licenciado com uma Licença Creative Commons - Atribuição-NãoComercial 4.0 Internacional. 


\title{
Iñaki Martín Viso, Asentamientos y paisajes rurales en el Occidente medieval
}

\author{
Gonzalo J. Escudero Manzano
}

\section{REFERÊNCIA}

MARTÍN VISO, Iñaki - Asentamientos y paisajes rurales en el Occidente medieval.

Madrid: Síntesis, 2016 (241 pp.)

\section{NOTA DO EDITOR}

Data recepção do artigo / Received for publication: 22-09-2017

1 O livro que apresento aborda a evolução do mundo rural no Ocidente europeu desde o século $\mathrm{V}$ a XV. Nele, o professor Martín Viso cria um quadro comum aplicável ao Ocidente medieval - isto é, a Itália, a França, as Ilhas Britânicas e a Península Ibérica -, que inavitavelmente nos lembra por estilo, metodologia e conteúdo, Chris Wickham e o seu célebre Framing the Early Medieval Ages, embora recorte o marco geográfico à pars occidentalis e amplie o temporal até o final da Idade Média. Esta cronologia tão extensa desenrola-se ao longo de cinco capítulos: os dois primeiros estão dedicados ao período altomedieval (séculos V a X), continua com outro para a Idade Média Central (séculos XI a XIII) e uma última secção que aborda os séculos XIV e XV.

2 Finalmente, como complemento ao conteúdo principal, encontra-se um apêndice de dezassete textos comentados pelo autor usados como exemplo para aspetos tratados ao longo da obra. O livro oferece também uma série de imagens e planimetrias estratigráficas para ilustrar o assunto da leitura. Fecha a monografia uma pequena seleção bibliográfica com as principais referências citadas. 
3 O início de cada capítulo repete o mesmo padrão: começa com uma alusão a uma unidade populacional concreta (El Pelícano, em Arroyomolinos - España; Flixborough, em Lincolnshire - Reino Unido; Wharram Percy, em Yorkshire - Reino Unido; Châtellerault, em Poitou-Charentes - França; e Gazzo, em Vercelli - Itália), que contextualiza e cuja evolução histórica comenta brevemente para assim entroncar num marco mais global similar ao caso de partida; pode-se comprovar como cada um dos exemplos pertence às distintas regiões do Ocidente europeu que se analisam ao longo do texto.

4 Como já indicado, o livro começa nos inícios do medievo. O primeiro capítulo, "Poblados y espacios agroganaderos en la Alta Edad Media" (pp. 15-53), situa no século $\mathrm{V}$ a formação dos assentamentos campesinos e as suas primeiras modificações desde o século VII até ao século IX. Trata-se dum capítulo que anuncia a metodologia a seguir durante toda a monografia: modelos comuns na Europa ocidental (mediterrânica e atlântica), utilizando fundamentalmente fontes materiais e arqueológicas, embora não descure o registro documental.

5 Seguidamente, em "Dominio social y territorio en la Alta Edad Media" (pp. 55-94), aborda a hierarquização do espaço rural através de lugares centrais, isto é, assentamentos fortificados geridos por elites locais campesinas surgidas a partir da desintegração do Império Romano de Ocidente. Neste contexto podemos distinguir duas zonas diferenciadas: por um lado, as localizações mediterrânicas herdeiras da territorialidade romana e, por outro, os modelos próprios do Noroeste europeu. Aqui, produziu-se uma rutura mais brusca, que implicou uma concentração do poder em torno de um líder militar com atribuições judiciais, e que assumiu contornos políticos estatais, graças ao apoio aristocrático. Estas elites locais projetaram a sua força mediante a fundação de igrejas para perpetuar a sua memória, e não com a intenção de cristianizar o território - como comummente se tinha pensado. Nos finais do século X, é já visível a capacidade das elites locais para transformar a paisagem e o território, tónica que se repetirá no futuro.

6 Em torno de 1300 vão surgindo as aldeias, com uma clara diferenciação regional, embora com caraterísticas comuns a todo o território analisado. Partindo deste paradigma, em "Aldeas y campos durante la expansión agraria medieval" (pp. 95-137), expõe-se como, por toda a Europa, os poderes senhorais vão controlando as comunidades campesinas, inserindo-as no seu aparato fiscal e social. Tal produz uma série de transformações no funcionamento das igrejas, que vão perdendo a sua influência, na hora de articular o povoamento aldeão a favor das infraestruturas laicas - fundamentalmente os castelos. De todas as formas, apesar de perder as suas funções de articulação territorial, os templos salvaguardaram a identidade local. As estruturas rurais que existiam desde os séculos altomedievais definiram-se e limitaram-se através dos senhorios laicos e da rede paroquial, ou seja, plasmou-se sobre o papel algo que já existia. Assim, a comunidade aldeã foi definida por uma série de relações internas expressadas na realização de atividades colectivas num território próprio.

7 Em "Paisajes del poder feudal" (pp. 139-180), Martín Viso analisa a formação das primeiras estruturas feudais. Estas produziram-se a partir de infraestruturas criadas ex profeso - como os castelos de mota - por parte da aristocracia política, como modo de plasmar fisicamente o poder senhorial. Estas elites, não obstante terem origem em famílias do século X com poder, seguiram padrões distintos dos das épocas precedentes. Relativamente ao contexto de construção premeditada de edifícios dominiais, assinala- 
se a visão que o autor oferece dos castelos, que - superando um dos tópicos mais difundidos - relaciona com o controlo sociopolítico, em lugar de os propor como estruturas vinculadas à atividade militar. Nesta proposta, afasta-se claramente dos já superados esquemas do incastellamento de Pierre Toubert. Contudo, a criação "desde cima" dos núcleos campesinos nem sempre foi bem sucedida, sobretudo quando se mostrou incapaz de atrair suficiente população.

8 No último capítulo, "Asentamientos y paisajes en movimiento (siglos XIV-XV)" (pp. 181-208), o autor apresenta as transformações que se produziram na Idade Média tardia, não como acontecimentos catastróficos, mas como resposta a uma nova conjuntura política, social e económica, cuja consequência imediata foi o despovoamento do mundo rural, a modificação das residências senhoriais - com o surgimento das casas fortes - e o avanço da exploração ganadeira. Este despovoamento deve ser entendido como parte de um largo processo que se iniciou no século XIII, e não como consequência de crises pontuais - como a Peste Negra ou as guerras. Foi a reação ao desenvolvimento da criação de gado em detrimento da agricultura, fenómeno que provocou o aumento da pressão fiscal em zonas cerealíferas e a diminuição da produção para autoconsumo. No entanto, a população não desapareceu biologicamente, antes emigrou, fundamentalmente para os centros urbanos. Os espaços também não foram completamente abandonados, mas abriram-se a novos tipos de exploração - granjas ou pastagens - ligados ao avanço da ganadaria. O último capítulo fecha, assim, o círculo acerca do mundo rural no Ocidente medieval: desde a origem do povoamento nos séculos altomedievais até à sua transformação nos alvores duma nova etapa: a Modernidade.

Dentro destes cinco temas, seria aconselhável haver um maior aprofundamento quanto ao mundo muçulmano - sobretudo andaluz. Não obstante, o autor justifica-o na introdução (p. 13): trata-se de um tipo de estudo muito diferente do prosseguido durante a obra, que entende não ser possível homogeneizar e articular, uma vez que o universo islâmico e o cristão são dois sistemas - políticos, culturais e religiosos completamente distintos. Contudo, não é inteiramente esquecido na obra, pois no terceiro capítulo é abordado o espaço fronteiriço com o Islão, como caso paradigmático da articulação territorial, já que o avanço cristão produziu um desmantelamento das estruturas prévias, cuja consequência foi a criação de uma territorialidade ex novo, de acordo com as necessidades do sistema de exploração feudal; por outro lado, no quarto parágrafo, é mencionada a projeção do modelo de criação de infraestruturas dominiais nas zonas conquistadas do Médio Oriente e no Al-Andalus.

Como balanço geral, qualifica-se a obra como manual de estudo para qualquer aluno que esteja a cursar ensinos relacionados com a História Medieval ou com o mundo rural europeu. Também é uma publicação adequada para uma divulgação dirigida a um público interessado, mesmo se não especializado na matéria. As explicações, as ilustrações, as planimetrias e, sobretudo, o apêndice de textos parecem perseguir tal fim. Estes últimos são especialmente proveitosos para o sector já citado: podem servir para práticas e trabalhos em aula. Já um leitor não versado no assunto pode usufruir das fontes primárias, graças aos comentários de um especialista. Ainda sobre o pontencial de divulgação da obra, deve notar-se o rigor das citações, notas e referências bibliográficas, pois não se perde o caráter científico da monografia e o leitor interessado - quer seja estudante, quer alheio ao âmbito académico - pode aceder a mais informação relacionada com o tema. 


\section{AUTORES}

\section{GONZALO J. ESCUDERO MANZANO}

Universidade Complutense de Madrid, Faculdade de Geografia e História, Departamento de História Medieval, 28040, Madrid, España

gonzaesc@ucm.es 